\title{
"I'm Not a Feminist ... I Only Defend Women as Human Beings": The Production, Representation, and Consumption of Feminism in a Telenovela
}

\author{
Carolina Acosta-Alzuru
}

$\square$ - This study examines a successful Latin American media product - the Venezuelan telenovela El País de las Mujeres [The Country of Women] - and analyzes how feminism and feminists are represented in it. Through interviews with the head writer and actors, the study also explores the production of these portrayals. In addition, consumption of the serial's representation of feminism is analyzed through individual and group interviewes with audience members. The study highlights the paradoxes involved in the production and consumption of a media text that simultaneously delivers a critique of Venezuelan patriarchy, an empowering message for women, and a sharp rejection of feminism.

66Feminism" and "feminist" are conflicted terms in all regions of the world. Latin America is no exception. Latin American women's movements have played a key role in improving the political, social, and legal conditions for women in the region. The relationship between these movements and the struggle against the authoritarian regimes that plagued the area during the 1960s and 1970s has been

Carolina Acosta-Alzuru is Assistant Professor in the Grady College of Journalism and Mass Communication, University of Georgia, Athens. Research for this article was funded by the University of Georgia Research Foundation and approved by the University of Georgia Institutional Review Board. An earlier version of this article received the 2001 James E. Murphy Memorial Award for Best Faculty Paper of the Cultural and Critical Studies Division of the Association for Education in Journalism and Mass Communication. The author thanks CSMC reviewers and co-editors for their thoughtful suggestions for revisions. widely reported and analyzed (Bousquet, 1983; Bouvard, 1994; Hensman, 1996; Jaquette, 1989; Navarro, 1989; Schirmer, 1993). This literature also delves into the region's rejection of the terms feminism and feminist, but the media's role in this disapproval has not been fully explored. This vacuum in the academic literature contrasts with efforts to examine the media's contribution "to the cultural conversation about feminism" (Dow, 1996, p. xiv) that has taken place in the United States (Blum, 1983; Clark, 1990; D'Acci, 1994; Dow, 1996; Lotz, 2001; Mayne, 1997; Mellencamp, 1997; Rabinovitz, 1989, 1999), the United Kingdom (Brundson, 2000; Hinds \& Stacey, 2001; Hollows, 2000; Read, 2000; Whelehan, 2000), and Australia (Lumby, 1997).

This study examines a successful Latin American media product - the Venezuelan telenovela El País de las $\mathrm{Mu}$ - 
jeres [The Country of Women] - and analyzes how feminism and feminists are represented in it. Through interviews with the head writer and actors, the study also explores the production of these portrayals. In addition, consumption of the serial's representation of feminism is analyzed through individual and group interviews with audience members. The study highlights the paradoxes involved in the production and consumption of a media text that simultaneously delivers a critique of Venezuelan patriarchy, an empowering message for women, and a sharp rejection of feminism.

Both telenovelas and soap operas are serial melodramatic genres that share the ambiguity of being successful and disdained at the same time. The Latin American telenovela, nonetheless, differs from the soap opera in important ways: (1) telenovelas have a finite number of episodes (120-200), therefore viewers expect a definitive conclusion to the story; (2) they are financed by television networks and broadcast both in primetime and in the afternoon block; (3) telenovelas - not Hollywood determine the stardom system for Latin American actors, and (4) because they perform in various telenovelas, the identities of actors are not tied to the characters they portray as is the case in the American soap opera system (Matelski, 1999).

My analysis draws on feminist media studies, heeding Jenny Kitzinger's (2001, p. 100) call for "more feminist work on media production, representation and influence." It also acknowledges, as recommended by Elspeth Probyn (2001, p. 35), that "the conditions of representation have changed as the dominant media take up certain ideas about feminism, gender, women and men." Gramsci's (1971) concept of hegemony is also instrumental to my analysis. Hegemony involves the production of consensus for cultural practices and ideas that will sustain power relations. Hegemony is fragile and always changing. It is not based on force but on "shared meaning and the appropriation of the meaning of life through power, seduction and complicity" (Martín-Barbero, 1993, p. 74). This conceptualization allows us to understand how a perceived ideological threat such as feminism can be defused through domestication and trivialization.

The deployment of hegemony has greatly influenced cultural studies' notion of popular culture as a crucial site of ideological conflict in which power relations of gender, ethnicity, class and identity are struggled over. This study draws on the cultural studies insight that media and culture are inextricably linked since "culture is concerned with the production and the exchange of meanings - the 'giving and taking of meaning' - between the members of a society or group" (Hall, 1997, p. 2). Recent cultural studies texts argue for an approach that studies cultural/ communication processes from multiple perspectives using the "circuit of culture" (du Gay, Hall, Janes, Mackay, \& Negus, 1997). Meaning is produced and negotiated in each of the circuit's moments - production, representation, identity, consumption and regulation. These meanings are necessary, but not sufficient, for determining the meanings embedded in the other moments (Barker, 2000).

In this case study of El Pais de las Mujeres, I use the circuit of culture as a tool to analyze how meanings associated with the words feminism and feminist are produced, negotiated and legitimized. I am concerned with the everyday engagement between feminism and a television serial genre tra- 
ditionally associated with female consumption, a telenovela, as meanings are produced at the writer's desk, in the actors' craft, and the audience's lives.

\section{Studying Telenovelas}

The traditional model of telenovela is characterized by a central story of heterosexual love in which obstacles and intrigues plague the main couple, who have to overcome these impediments and schemes in order to achieve happiness together. The two main characters usually have different socioeconomic origins; therefore, their love story is also about socioeconomic advancement. Most of the tribulations suffered by the main couple are produced by the dramatic presence of triangles - two men in love with the same woman, a man loved by two women (Klagsbrunn, 1993). In addition, the ignorance of an identity is always central to the story. Becoming blind, crippled and/or pregnant are also staples of the genre, whose heroines experience these situations, only to overcome them before the happy ending. Traditional telenovelas, known as telenovelas rosa, are characterized by "heart-rending, tragic suffering" (p. 279) and one-dimensional characters that offer a Manichean view of social roles - the villain is pure evil and the heroine is sweet, virtuous and naive.

In contrast, so-called telenovelas de ruptura ${ }^{1}$ break with this traditional mold, as they include social and cultural issues taken from Latin American reality. These telenovelas present complex, ambiguous and unpredictable characters. In addition, these serials combine personal and social problems in a narrative fiction that speaks to the audience in terms of a shared reality (Martín-Barbero \& Rey, 1999). Most Venezuelan telenovelas follow the traditional model. El País de las Mujeres is an exception. It is a Venezuelan telenovela de ruptura broadcast to high ratings in Venezuela, Argentina, Peru, Puerto Rico, and the United States. ${ }^{2}$ El Pais presents an ensemble cast of multifaceted characters, an array of couples, and stories centered on the everyday life and struggles of women, highlighting topics such as sexual harassment, abortion, and domestic violence.

Latin American scholars have been at the forefront of academic research into telenovelas. In the $1970 \mathrm{~s}$, Latin American communication scholarship was influenced by theories of cultural dependence and media imperialism, rendering a picture of telenovelas as alienating products directed at audiences described as passive victims (Beltrán, 1978; Colomina de Rivera, 1974). Country-specific studies dominated the research agenda, including the work of Rector (1975) about Brazil, and Coccato's (1979) historiography of Venezuelan telenovelas. In addition, this decade saw the theoretical work of Moraña (1978) and Verón (1978) that established semiotics as one of the dominant approaches to the study of the genre.

In the 1980s and 1990s, Latin American communication scholars drew on sociology and cultural theory to create a research stream known as Latin American cultural studies (Murphy, 1997; O’Connor, 1991). These researchers gave audiences credit as they attempted to understand the intricate relationship between telenovelas and Latin America's uneven modernity. An important body of literature 
was developed as scholars searched for a theoretical framework to explain how telenovelas are linked to questions of nationality, cultural identity, and modernity (Aprea \& Mendoza Martínez, 1996; Fadul, 1993a, 1993b; González, 1993; Lopez, 1995; Lozano, 1989; Martín-Barbero, 1987, 1988, 1993, 1995; Martín-Barbero \& Muñoz, 1992; Martín-Barbero \& Rey, 1999; Verón \& Chauvel, 1997).

Empirical studies looked at telenovelas from different perspectives. Production and marketing were examined in Brazil (Sodré, 1977; Tavola, 1984), Perú (Quiroz, 1993) and Mexico (González, 1988). Textual and content analysis included the work of MartínBarbero and Muñoz (1992) and Lager (1992) about Colombian telenovelas, and Geddes-González (1993) and Quiroz (1993) in Perú. Audience studies focused on the insertion of telenovelas in each country/culture's everyday life: Brazil (Borelli, 1997; Klagsbrunn, 1997; Sluyter-Beltrão, 1993; Tufte, 1993), Mexico (Bustos-Romero, 1993; González, 1993; Uribe Alvarado, 1993), Argentina (Mazziotti \& Borda, 1997), Colombia (Muñoz, 1992) and Venezuela (Barrios, 1988; Mendoza, n.d.). Some scholars examined the intersection between telenovelas and the social formation. For instance, Porto (1998) studied the role of telenovelas as a key forum for the discussion and interpretation of political issues in Brazil, and Estill (2001) analyzed the "foundational fictions" of the Mexican telenovela, searching for the basic narratives that help constitute the ideological construct of a coherent nation.

American and European scholars have also become increasingly interested in telenovelas during the last two decades. Early research hailed the genre's importance. For instance,
Rogers and Antola (1985) noticed how these Latin American products successfully competed with United States imports, Vink (1988) examined the potential for social change of Brazilian telenovelas, and Straubhaar (1988) analyzed the relationship between these serials and political changes in Brazil. In 1995, Allen edited a volume that investigated soap operas around the world. Three chapters are dedicated to telenovelas (Baldwin, 1995; Lopez, 1995; Martín-Barbero, 1995). In addition, Allen's introduction highlights the increasing importance of the Latin American genre. European scholars have also recognized the importance of telenovelas. In Italy, Pozzato (1995) used a semiological approach to study the rosa melodramas. In Spain, Guaderrama (1995) analyzed the Spanish press coverage of the telenovela boom that Spain experienced during and after the broadcast of Venezuelan telenovela Cristal. In a study about soap operas in western Europe, O'Donnell (1999) described the success of Latin American telenovelas in Spain and Russia. In addition, he looked at telenovelas produced in Portugal and Spain, tracing their roots to Latin America. Matelski's (1999) book, Soap operas worldwide, is an ambitious global survey of soap operas and telenovelas. Organized by regions and countries, her book includes general broadcasting information plus lists and synopses of the most successful serials. In 1994, McAnany and La Pastina reviewed existing telenovela audience research. Later, Tufte (2000) examined the sociocultural role of telenovelas in Brazilians' everyday life, and La Pastina (2001) analyzed product placement in Brazilian telenovelas.

Still, the most extensive body of academic research focusing on telenovelas is Latin American. And even 
though telenovelas have been studied from different perspectives (production, text, reception), there is a lack of comprehensive studies that simultaneously examine two or more aspects, such as production and reception, or text and reception. As Tufte (2000) explains, comprehensive empirical studies are still the weakest aspect of communication research, and telenovela scholarship is no exception.

\section{Feminist Media Studies, Hegemony, and Culture}

The last 20 years have seen the growth and establishment of feminist media scholarship as a line of academic thought and research of great influence in communication studies and related fields. Feminist media studies' theoretical roots, themes, methods, and major works up to 1994 have been outlined by van Zoonen (1994), while recent developments and future challenges are chronicled in the inaugural edition of the long-awaited journal Feminist Media Studies (2001).

Representation has been a major concern in this transdisciplinary area of inquiry, since "the women's movement is not only engaged in a material struggle about equal rights and opportunities for women, but also in a symbolic conflict about definitions of femininity (and masculinity)" (van Zoonen, 1994, p. 12). The representation of feminism is also key to the symbolic struggle that is the focus of feminist media studies. Recent scholarship has examined such representations in advertising (Goldman, Heath, \& Smith, 1991), print media (Anderson, 1999; Danner \& Walsh, 1999;
Hinds \& Stacy, 2001; Lind \& Salo, 2002; Read, 2000) and television (Clark, 1990; D’Acci, 1994; DellingerPate \& Aden, 1999; Dow, 1990, 1996; Lotz, 2001; Mayne, 1997; Rabinovitz, 1989, 1999; among others). These scholars have found the presence of backlash themes (Faludi, 1991) and evidence of the hegemonical incorporation of bits and pieces of feminism that may contribute to the perpetuation of patriarchy and traditional views of women. For instance, in her analysis of The Mary Tyler Moore Show, Dow (1996, pp. 50-51) argues:

Certainly, hegemony is at work in Mary Tyler Moore. Mary's independence is consistently compromised by her submission to others' needs, and the sitcom's naturalizing of her "true woman" qualities (particularly in comparison to other female characters) reflects little awareness of the radical feminist critique of gender roles. A potentially threatening idea (a woman on her own) is made less threatening when she is slotted into familiar roles and relationships that assure the audience that little has really changed.

The hegemonic process, then, is fraught with contradictions because media texts are crucial sites of negotiation and friction over meanings that strive to be established as dominant, or naturalized as "common sense." A telenovela de ruptura like El Pais de las Mujeres presents a fictional world that has connections with, and draws on, discourses present in the social formation. Therefore, this study embraces cultural studies' broad conception of culture as a "site of social differences and struggles" (Johnson, 1986/87, p. 39). It is a notion of culture that stresses lived experiences, legitimizes popular culture as a valid research topic, and focuses on conflicts over meanings. This conception of culture renders a 
brand of cultural studies that looks not only at texts, but also at their production, consumption, and their influence in the regulation of cultural life. It also shares with feminist media studies the understanding that the study of culture and communication is both an intellectual and a political endeavor.

Cultural studies scholars have looked for theoretical frameworks that allow comprehensive studies of cultural/communication processes. Based on Richard Johnson's (1986/87) model of the production, circulation and consumption of cultural products, scholars from the Open University have developed a model of the "circuit of culture" that depicts the cultural process as a complex and interdependent set of moments that are distinct, but not discrete, and accepts Johnson's proposition that the study of individual moments only gives us a partial view of how the meanings associated with a particular cultural product are produced, negotiated, and contested (du Gay et al., 1997). The model, a blueprint for how to conduct cultural studies, addresses criticism that expresses discomfort with cultural studies' emphasis on textual analyses over the study of audiences (Jensen \& Pauly, 1997), and annoyance at the perception that cultural studies focuses on cultural consumption rather than on cultural production (Garnham, 1997; Levine, 2001). In addition, it acknowledges feminist media studies' preference for interpretive, multiperspectival research (van Zoonen, 1994).

The circuit consists of five moments: representation, identity, production, consumption, and regulation. It emphasizes the relationship between culture and meaning, which is "constructed - given, produced - through cultural practices; it is not simply 'found' in things" (du Gay et al., 1997, p. 14). Meaning is transacted in each of the circuit's moments. Representation refers to the production of meaning through language, highlighting the symbolic underpinnings of culture. Identity alludes to how a cultural product acts as a marker that identifies a particular group - in other words, how meanings create an identity. Cultural products are also encoded with meanings in their production process. They are produced in ways that make them meaningful. But meaning is also produced when we make use of the cultural product in our everyday life. Consumption looks at what the product means to those who actually use it. Finally, regulation examines how meanings organize and regulate cultural practice.

Telenovelas are a cultural/media product in which articulations between the moments of the circuit are evidenced. Martín-Barbero (1987, 1993) argues that the telenovela is a site of mediations between production, reception, and culture. There is constant negotiation between the writers, director, production team, actors, audience, and institutions that participate in the social formation. In addition, telenovelas provide us with a perfect example of how production and consumption, traditionally represented as opposing forces, are deeply articulated (Quiroz, 1993). In sum, the circuit of culture provides an organizational tool for this study - grounded in feminist media studies and cultural studies - which attempts to understand the contradictions involved in the production, representation, consumption, and regulation of a feminist identity through El País de las Mujeres, and how these are embedded in Venezuelan culture. 


\section{Context: Venezuelan Women, Venezuelan Culture}

Social, Political and Ideological Underpinnings

There is a strong connection between Latin America's patriarchy and the Catholic doctrine that dominates the region. This is especially evident in three interconnected ideological areas: the myth of the patriarchal family, the presence of machismo and marianismo, and the prevalence of the Virgin:whore binary opposition. These three constructs underpin and reinforce the particular brand of public/private dichotomy that subordinates women in Latin America. ${ }^{3}$

The patriarchal family is considered the ideal (and natural) societal unit. Women are then responsible for the care of the domestic (private) environment, while men are in charge of the public sphere. The system of social relations is anchored, in this way, to the male-headed household (Jelin, 1990). In reality, however, Latin American female-headed households are almost as common as patriarchal ones (Cicerchia, 1997; Dore, 1997). Nevertheless, Latin American society functions under the assumption of the prevalence of the male-headed household.

This assumption is connected to the dominant ideologies of machismo and marianismo. Machismo is the belief that men are superior to women, have more extensive rights, and belong to the public sphere while women should stay in man's shadow and in the private realm. Marianismo, a "cult of female spiritual superiority" (Stevens, 1973 , p. 91), holds that women are morally superior, owners of spiritual strength and a capacity for selfsacrifice that renders them fit to be good mothers. The combination of these two ideologies places women in the private sphere of the household and assigns them the brunt of parental responsibility.

Marianismo is based on the figure of the Virgin Mary, who represents the epitome of the private sphere, and is always portrayed as "an idealized woman who is an obedient, selfsacrificing mother, subordinating her needs to those of her children, [she] obeyed the wishes of her son, Christ, and of other men including the disciples and God himself' (Stephen, 1997, p. 35). The counterpart image of the Virgin is the whore (based on the biblical Mary Magdalene), who is seen "as aggressive, impure, disconnected from motherhood, and a male sexual object. Her sexuality is constructed to service men, and her personhood (if she is granted any) is focused through this role" (Stephen, 1997, p. 35). The whore is defined by the term mujer pública [public woman], which means prostitute in Latin America, equating, in this way, women in the public sphere to prostitution. Latin American women are continuously teetering between these two images. As Stephen (1997, p. 35) notes, "women who deviate from the characteristics associated with the Virgin Mary by disobeying the state authority and assuming an active role in society can be cast into the opposite role of symbolic whore."

In sum, through these three interconnected ideological constructs - the myth of the male-headed family, machismo and marianismo, and the Virgin:whore dichotomy - the Catholic Church in Latin America defines gender roles and proper female behavior, while reinforcing patriarchy and its ensuing female subordination. In this way, women become the other, in op- 
position to whom the normal is defined (Juliano, 1998).

\section{Women (and Men) in Venezuela}

These ideological underpinnings have important consequences for the everyday life conditions of women and men in Latin America in general, and Venezuela in particular. For instance, even though in the last three decades Venezuela has seen a decline in birth rates ${ }^{4}$ and an increase in women's participation in the workforce, ${ }^{5}$ most women are still conceptualized as belonging in the private sphere. Increasing participation in the workforce can be misinterpreted as a sign of women's emancipation. However, for most Venezuelan (and Latin American) women, working is a matter of survival. In Venezuela, women head 25\% of all households. Moreover, women head half of all poor households (JUVECABE as quoted in Friedman, 2000). Given these circumstances, in most cases there is no relationship between earning a wage and empowerment (McClenaghan, 1997). Furthermore, women who enter the workforce find that most of the jobs open to them are in the service sector, pay low wages, require low skills, and offer limited opportunities for advancement. ${ }^{6}$ Hence, the entrance of women into the workforce is not the product of an ideological change in the social formation; it is merely the outcome of financial need. In addition, women who work outside their homes are still responsible for domestic work, and expected to juggle multiple roles. Even when a woman has the resources to pay for help, she is still responsible for the supervision of her helper (who is usually a woman) (Inter-American Development Bank, 1995).

The conjunction of marianismo and machismo has other consequences for the everyday life of Venezuelan women. First, there is a significant incidence of male infidelity and a sociocultural legitimization of this behavior. That is, there is high tolerance for, even acceptance of, male infidelity (Esteinou \& Salles, 1996). On the other hand, women's infidelity is not socially sanctioned. Second, domestic violence is a widespread problem that transcends class and age differences (InterAmerican Development Bank, 1995). Third, abortion is illegal, unless the mother's life is in danger.

Another sociocultural area in which machismo has an influence is in attitudes towards sexual orientation. Machismo, coupled with Catholicism, underpins Venezuelans' sweeping rejection of homosexuality. Gay men and women are the butt of jokes and the laughing stock of a popular culture that mercilessly stereotypes them as freaks - effeminate men and masculine women. In Venezuela, homosexuality is only beginning to carve a social space.

An important element of the everyday life of Venezuelan women is the emphasis Venezuelans place on physical beauty. In a recent Roper poll, Venezuelans topped a list of 30 countries as the people most preoccupied with their physical appearance:

$65 \%$ of women say they think about the way they look all the time, as do $47 \%$ of Venezuelan men. These figures are well beyond the global average, which is $23 \%$ of women and $16 \%$ of men who say they think perpetually about the way they look. (Goode, 1999, p. 4)

In a country where $80 \%$ of the population lives below the poverty line, spending a fifth of income on personal 
grooming and care is not uncommon (Rohter, 2000). Looking good is given tremendous importance. The broadcast of the Miss Venezuela beauty pageant is similar to the Super Bowl, with high ratings and expensive advertisements. Even coffee table books featuring the country's stunning beaches, mountains and jungles, now include photos of the pageant and its contestants, making Venezuelan women an official part of the country's landscape (Gazsó, n.d.). In this environment, women's search for a better physical appearance is one more unavoidable duty and an important element in women's objectification.

These are some of the conditions that define women's (and men's) everyday life in Venezuela. Women's lives are centered on reproductive responsibilities and taking care of others which in turn, defines their moral worth. Women endure infidelity and, in many cases, violence. And their participation in the workforce is framed by patriarchy "in a context where no alternative ideological models exist" (González de la Rocha, 1994, p. 290).

\section{Feminism in Venezuela}

According to longtime Venezuelan feminist scholar Gioconda Espina, the predominant meanings associated with the term feminist in Venezuela are man haters, public militants and lesbians (personal correspondence with Gioconda Espina, 2001). In addition, Venezuelan women have been under great societal pressure to forego the feminist label. For instance, in 1985, the socialist party Movimiento al Socialismo [Movement toward Socialism] (MAS), which had been at the forefront in its promotion of women's activism, insisted on a change of name for its Frente Feminista [Feminist Front] arguing that "the word feminist had been largely discredited and that the party would be more effective if it appealed to women in their condition as members of a household and as workers rather than feminists" (Ellner, 1988, p. 187). To make matters worse, the Feminist Front was moved to the party's area of unconventional social movements (Friedman, 2000).

Another example of the Venezuelan rejection of feminism can be seen in the process that culminated with one of the greatest achievements of the women's movement, the 1982 reform of the civil code, which finally matched women's legal rights to those of men and eliminated legal discrimination against children born out of wedlock. To accomplish this, women built coalitions between different groups and used a family-oriented discourse that explicitly avoided any association with feminism. The reform was not promoted as a women's rights issue, but as a necessary improvement for families that would benefit all members of Venezuelan society. ${ }^{7}$

In sum, Venezuelan women have often taken "great pains to deny that they [are] feminists" (Friedman, 2000, p. 280), since feminism has been generally associated with the subversion of traditional gender roles, which are considered one of the cornerstones of Venezuelan society. This cultural rejection of the term feminism, and the everyday conditions that define women's and men's lives in Venezuela, provide the context for this study.

\section{Methods}

This study, part of a larger multimethod cultural analysis of El Pais de las Mujeres, uses the circuit of culture as 
a tool to examine how meanings associated with the terms feminism and feminist are negotiated. The representation of feminism, and the ensuing creation of a (feminist) identity in El Pais were examined through textual analysis of the telenovela. Individual interviews with the head writers and actors allowed me to study the production of meanings. These conversations also provided insight into the moment of regulation. Consumption was examined through individual and group interviews with audience members.

\section{Textual Analysis}

One of the epistemological assumptions of this study is that meaning is a social production, and as such is embedded in issues of power. Textual analysis recognizes this postulate since it considers the conditions of production and consumption of the text. Unlike content analysis, the text is not the end in textual analysis. It is the means by which we study a signification process, a representation of reality.

The text analyzed included all episodes of El País de las Mujeres. Because the original text is in Spanish, the analysis was conducted in Spanish. The author translated the excerpts in this article. Throughout the analysis, the objective was to find how the meanings of feminism/feminist are produced through language and visual images, and how these meanings create an identity - the feminist.

\section{Interviews}

In-depth interviews with head writer Leonardo Padrón and with actors were conducted in Caracas, Venezuela. These semi-structured conversations took place at a time and place chosen by each participant. Nine El Pais actors were interviewed, plus two longtime Venezuelan actors, and one actor/producer/writer who did not participate in this particular telenovela, but who provided background information on the Venezuelan telenovela industry. Actors were interviewed once for one to two hours in May 2000. Actor Orlando Urdaneta, who lives in Miami, was interviewed on the phone in August 2000. Padrón was interviewed twice (May and December 2000). His interviews lasted for three and two hours respectively. I prepared different interview guides for the actors and for Padrón, given their different roles in the production process.

Also, 39 audience members were interviewed in May 2000, either individually or in small groups. For instance, one group consisted of a family that usually watches the prime time telenovela together. Another group consisted of three women who work in the same company. In addition, couples who watch telenovelas together were interviewed together. Participants were recruited using the snowball sampling technique (Brown, 1994; Press, 1991; Rubin, 1986; Weiss; 1994). The group of participants was heterogeneous: 32 women and 7 men participated; their age range was 18-75; and they belong to the five socioeconomic strata present in Venezuela, A to E (Proyecto Pobreza, 2002); six class A (the most affluent), five class B, 10 class C, 10 class D, two class E, six don't know/ don't answer. Participants are also diverse in their education level (elementary, incomplete high school, high school, undergraduate, graduate), and their marital status (single, married, divorced, widowed); 11 are professionals (architects, accountants, engineers, medical doctors, psycholo- 
gists), two are teachers, seven are secretaries or receptionists, three work as maids, two are retired, three have never worked outside their homes, and 11 are students.

The length of these interviews ranged from one to two hours. Some interviews took place at the participants' homes (when there was a VCR available), while others were conducted at a central location in Caracas set up with a television and VCR. An interview guide was prepared along with a videotape with excerpts from $E l$ Pais that were used as prompters for the conversation. At the end of each interview, participants were asked to fill out a form with demographic data and information regarding their general television viewing habits.

All participants signed informed consent forms prior to our conversations. Interviews were conducted in Spanish, audiotaped, transcribed, and translated by the author. Pseudonyms were assigned for confidentiality. ${ }^{8}$ In addition, extensive notes were taken at the end of each meeting documenting my impressions of the interview and its participants.

\section{Analysis}

\section{Women and "the Feminine"}

Head writer Leonardo Padrón conceptualized El Pais as a "telenovela with a thesis," in which he would showcase Venezuela's "most emblematic feminine archetypes." The main setting is urban: Caracas, Venezuela's capital of five million. The storylines present conflicts that are centered not around the traditional telenovela theme of social advancement, but on love, family, and work. The main female characters (Arcadia, her five nieces and her friend Catalina) portray different facets or sides of women: strength (Arcadia), sensibility (Mariana), romanticism (Julia), rebelliousness (Miranda), determination (Pamela), idealism (Chiqui) and redemption (Catalina).

Throughout El Pais, women struggle with and resist the dominant Venezuelan view that women are defined by the men they are with. The telenovela ridicules the objectification of women and other negative representations, such as women as wild animals in need of domestication and women as servants, by depicting the (usually male) characters that hold these views as caricatures, and by presenting clever twists of the plot that underscore the unfairness of these attitudes. For instance, Arsenio leaves Arcadia and their marriage of 25 years for a young woman, a former prostitute who he simply calls el hembrón, a demeaning Venezuelan expression used by men to describe a beautiful woman with a perfect body.

Arsenio: why did I leave you for another woman? Because I was sick of you, Arcadia. No, not sick, but bored, that is, bored! Because your face bored me, because life had become a yawn ... always the same comments, the same food and making love the same way for 25 years, no! No! Too long! And with an added bonus... that you're done, that you're wrinkled, that you're old!

This view is common in Venezuelan popular culture. Older women are the butt of jokes that contrast them with their younger counterparts, stressing that, because of their age, they cannot compete for men's affections anymore. The dominant view is that as women age they become ugly, boring, and worthless. This conceptualization of older women is linked to Venezuelan standards of physical beauty. Female characters in El País are acutely aware of this, and repeatedly voice their 
opinions regarding the injustice of a society in which men do not age, but women do. In an empowering twist of the plot, Arcadia, disdained by her former husband because of her age, marries Daniel, a man 15 years younger than herself, while Arsenio finds death at the hands of his lover. Furthermore, Arcadia and Daniel's love story includes lovemaking scenes as sexy and tender as those of the younger couples. In this way, Arcadia's story validates middle-aged women in a society that seems to have no use for them.

The telenovela, however, is not devoid of criticism towards women. Female characters are not merely good or evil. They have a realistic mix of traits, including determination, passion, and honesty, but also excessive ambition, lack of scruples, and insecurity. In addition, El Pais sharply criticizes the national overuse of plastic surgery by mocking the dominant Venezuelan idea that perfect physical beauty is a key ingredient in the search for happiness.

Audience members declared in interviews that El Pais has a clear message: to emphasize the qualities, rights and struggles of Venezuelan women. According to participants, the telenovela delivers this message through realistic portrayals, which make for a balanced, authentic representation of women:

It presents how Venezuelan women really are: venturers $[. .$.$] Women are no longer$ the protected ones. Women show that they can be, and [in the telenovela] it is evident that these women are all capable, each one in their own area (MILAGROS, $38)$.

For some participants, this telenovela was important for its representation of the daily struggles faced by women. As NORA (47) explained, "they present how Venezuelan women really live," denying stereotypical views of women as "la quinta hornilla de la cocina [the fifth burner in the stove]."

One of the most important female characters is Miranda, who Padrón defines as "lucid, proactive and assertive." Miranda is an engineer who works at the Venezuelan oil rigs, where she is the victim of sexual harassment by a male engineer obsessed with her. As a teenager, Miranda was molested by her aunt's husband, Arsenio. These experiences have turned her against men. Most of the time Miranda dresses in black. Leather is a regular part of her wardrobe, which contrasts with those of the other female characters as being poco femenino [not very feminine]. Actor Carolina Perpetuo, who played Miranda, explained that she carefully and purposefully chose the character's clothes, exercised, and cut and colored her hair to make Miranda's physical appearance that of a striking, intense though unconventional - woman. Miranda is a strong character who speaks her mind and is determined to be her own person. When she is fired from the oil company, she decides to work as a bartender, and falls in love with the restaurant's chef, Diego. By Venezuelan standards, Miranda and Diego are not a traditional couple. They live together without being married. And, in a reversal of traditional roles, he cooks for a living while she mixes drinks in a bar. When Diego gets a flat tire, it is Miranda who knows how to fix it. Her relationship with Diego, in addition to her looks and forthright attitude, reinforces $\mathrm{Mi}$ randa's transgression of traditional gender roles and of the Venezuelan feminine.

In his assessment of the telenovela, CESAR, an audience member, repeat- 
edly defined Miranda as a "resentful woman" who is "extremely crude and sour, nothing about her is positive." He sees her as a useless character who neither reflects Venezuelan women, nor contributes to the quality of the telenovela. Many of the participants disagreed with GESAR, describing Miranda as strong, courageous and outspoken. Her relationship with Diego is assessed as one of the best in the telenovela. However, Miranda's appeal is not uniformly distributed among the group interviewed. It is stronger among those participants in the 25-45 age range. The other age groups find her "a bit extreme and strange." This difference suggests that Miranda's acceptance among these participants is linked to the latter's understanding of how women should look and behave.

Miranda's transgression of the feminine and of traditional gender roles gave Padrón and actor Perpetuo problems. According to the writer, when the telenovela was broadcast, people started commenting that Miranda was a lesbian:

From their moral codes, people decided ... and since Miranda hadn't fallen in love with any man in the telenovela, and she had an assertive manner, independent, autonomous, working in an oil rig in Lake Maracaibo ... people decided that she was gay, which is a really simplistic and Manichean way of looking at the different shades of being a female.

Both Perpetuo and Padrón thought that this was a dangerous reading that could jeopardize the telenovela's success, given Venezuelans' traditional homophobia. (It should be mentioned that once the telenovela had established itself as an unqualified success, Padrón who believes that "it is imperative to carve space for homosexuality in
Venezuelan society" - criticized homophobia through a storyline that included a stable homosexual couple. However, the author was not willing to risk the telenovela's ratings before they were firmly established). Padrón decided to correct the audience's reading through Miranda herself. He wrote some dialogues in which a minor character asks Diego, who is already in love with Miranda, if he has not considered the possibility that Miranda might be gay. In reaction to this comment, Diego asks Miranda if she is a homosexual, to which she replies:

Gay! Why? Because I'm not flirting with men? Because I don't like doing that? Because I think that the majority of men are like animals in heat all the time? Or because I think that men are too elemental, too predictable and too machos for my taste? [...] It really doesn't offend me that you ask me that because I respect people's sexual orientation. You know what offends, assaults, and irritates me? That people are reaching conclusions about me, especially when nobody knows the things that I've lived, and nobody knows the damage that men have inflicted on me.

In this way, the writer rectifies the audience's appraisal of Miranda. Moreover, Padrón scolds the public for their simplistic views of the feminine, and the homophobia that underpins many of their attitudes.

Only one participant admitted she had believed that Miranda was gay (ANDREA). One possible explanation is that the interviews took place after the telenovela had ended. Therefore, participants had already been reprimanded by Padrón. Under these circumstances, it is understandable that only one viewer was willing to acknowledge being mistaken.

The portrayal of Miranda also produces another unintended and unde- 
sirable response. The emphasis placed on Miranda's traumatic past backfires, producing the undesired effect of equating outspoken, assertive women with traumatized women. In consequence, Miranda's assertiveness is watered down, and rendered as the exception, not the norm, reinforcing traditional conceptualizations of the feminine as docile and quiet.

\section{Men, Machismo, and Women}

Padrón also presented a set of archetypical male characters who represented machismo (Lucas, Rodolfo, Arsenio), corruption (Rodolfo, Arsenio), and honesty (Camilo, Jacobo, Diego). The author was determined to fight "the stereotypical view that all Venezuelan men are worthless and at fault when a relationship collapses." He accomplishes this through the character of Jacobo, el hombre ideal [the ideal man]. This character is the example that counters the generalization that all men are bad. Jacobo is married to Chiqui. They have a daughter of nine. Their marriage is marred by constant arguing that showcases typical marital disagreements and highlights their personality differences (for example she is vegetarian whereas he loves meat). Even though Jacobo and Chiqui reconcile several times, they end up getting a divorce. Throughout their rocky relationship, Chiqui's explosive character contrasts with Jacobo's even temperament. And, even though their story is an insightful exploration of married life, it is easy, perhaps too easy, to side with Jacobo who continuously displays consideration toward women and an exceptional understanding of their plight. He also contrasts with other male characters like Lucas, Arsenio, and
Rodolfo who are archetypical machos, treating women as either a trophy to be owned or as food to be consumed. ${ }^{9}$

According to Padrón, Jacobo is his alter ego, the character through which he delivers his vision of man/woman relationships, and of the country. The actor chosen, Orlando Urdaneta, is Padrón's longtime friend and a beloved figure in Venezuela. Urdaneta and Padrón share critical positions towards Venezuelan society. In particular, Urdaneta's criticism of the country's corruption is well known. Jacobo personifies Padrón and Urdaneta's shared attitudes towards Venezuela, and Padrón's assessment of the state of Venezuelan couples. Jacobo's perfection, however, became an issue among Padrón's team of (female) writers. These women argued that Jacobo was muy perfecto [too perfect] and that there are no men like Jacobo in Venezuela. This view was echoed by actor Lourdes Valera who played Jacobo's wife, Chiqui: "Someone like Jacobo doesn't exist."

Audience members loved Jacobo. Many participants declared that he was their favorite character, and wished that there were more Jacobos in Venezuela. In addition, audience members interviewed unanimously expressed that the majority of the male characters personify machismo, "with the exception of Jacobo, the rest were all great machistas" (HILDA, 63), unsavory characters who "injure women" (GRACIA, 65). Furthermore, participants believed that the telenovela's male portrayals were accurate and realistic. One woman even ventured: "In this novela they show men as they are. Actually, there are lots of men like that. Some would say: well, no, maybe this is not true ... I say they fell short of reality!" (LAURA, 44). Some participants felt that, despite Jacobo's pres- 
ence in $E l$ Pais, the emphasis on machismo provides a darker, more negative depiction of men than of women. They still insisted, however, that it was realistic: "It's Venezuelan reality, that is, we find machistas every day" (CLARA, 43).

In addition to the inclusion of machista male characters, El Pais's criticism of machismo involved stories that displayed women's daily struggles and triumphs by underscoring the double standards between men and women that dominate Venezuelan society. As actor Carolina Perpetuo (Miranda) said:

Latin American societies are very severe with women, placing great expectations on them. [...] Culturally, women suffer a programming of sorts towards abnegation, sacrifice and pain. [...] Even in the marriage one has to tolerate that the husband has a lover, because that is normal and one has to save the marriage. [...] It's like a Calvary.

This telenovela attempts to break this "programming towards abnegation" by exploring topics such as abortion, working mothers, marriage, divorce, and, especially, machismo and domestic violence. The latter is presented through the marriage of Lucas and Catalina; he is continuously unfaithful to her and puts her down at every opportunity. At the same time, he expects her to produce perfect meals, ironed shirts, a clean house, and to have no thoughts or opinions of her own. Lucas's violence towards Catalina is mostly psychological, although he does hit her once. Catalina leaves Lucas and thoroughly changes her life: she stops the vicious cycle of self-deprecation in which Lucas has placed her, learns about the new Venezuelan laws that protect women from domestic abuse, finds a job, earns a college degree, and remarries. This is Padrón's homage to women, to show "women's redemption and, in some way, use a flashlight to light the way [to redemption] for those who still don't know how to redeem themselves."

The public's reading of Catalina is consistent with Padrón's intentions. Domestic violence, which the writer considers "the country's worst social problem" and the extreme form of "Venezuela's cultural pattern of subordinating women," is welcomed by the audience as a topic in need of analysis. The empowering message of the woman who decides to change her life and become her own person is, for many of this study's participants, the most important lesson in El Pais:

Yes, Catalina changes her life and her mentality, and says, "I can be another woman that is not her husband's subordinate." Women can regenerate their lives and take a different route without having to tolerate what she had to. (MARTA, 50)

It's well presented because it shows women who have suffered through this type of thing, that there is a way out. (ANDREA, 32)

Actor Elba Escobar, who played Catalina, became a symbol of the plight of abused women. She was invited to panels and fora that discussed the issue, and in the streets women stopped her to thank her. At the same time, the Consejo Nacional de la Mujer [Women's National Council] publicly congratulated Padrón for directing the spotlight towards domestic violence, and offered him further information on the problem and its legal ramifications, which he included in Catalina's storyline. In this way, the writer accomplished his goal of showing women a way out of domestic violence. 
This goal, however, is laden with contradictions. Through his telenovela, Padrón offers Venezuelan women important information about domestic violence and women's legal rights. $\mathrm{He}$ also offers a credible character who overcomes this widespread problem. At the same time, however, there is an element of victim blaming in Padrón's intention to show women how to redeem themselves. This element is linked to Padrón's understanding of feminism, which is analyzed in the following section.

\section{Feminism}

Even though this telenovela's storylines and characters criticize women's oppression as they attempt to inform and empower women, El Pais - paradoxically - does not represent feminism in a positive light. None of the characters identifies him or herself as a feminist. On the contrary, all characters express negative views of feminism. Feminists are referred to as "irrational", "wild" and "cuaimas [poisonous serpents]."10 Well-known misconceptions about feminists - superwoman, mujer pública, man haters, aggressive - are present in El Pais. For instance, when Rodolfo (a machista plastic surgeon) and his fiancée Mariana argue about her determination to keep on working and studying once they are married, he tells her:

If what you want is to be on the streets, being wonder woman, journalist of the year 2000! Then, it's fine, but I'll tell you something: go find a man who tolerates it, because I, Rodolfo Matamoros, am not going to stomach your feminist manifesto!

Every time a female character refers to, or complains about, the multiple roles women juggle on a daily basis, the machista male characters dismiss this as a discurso feminista [feminist discourse], diminishing both feminism and the burden that women carry with their multiple responsibilities.

It is not only unsavory male characters like Rodolfo, Lucas, and Arsenio who voice negative opinions of feminism. Even the ideal man Jacobo expresses negative views of feminism. Moreover, feminism is defined as an extreme, emotional discourse by the female characters, who often apologize for their emotional outbursts against men by saying, "I acted like a feminist." In a conversation in which the five cousins are pondering whether all men are the same, Miranda expresses her views of men as "selfish beings interested in only one thing from us women, and it happens that I have the bad habit of considering myself as a whole, complete human being." To this, her sister Pamela replies, "Miranda, please! There is nothing more fatuous than being a feminist."

Even though Padrón sets out to honor Venezuelan women by presenting them as protagonists of their own stories, he stated:

I didn't want to do a feminist telenovela [...] as I understand the term, that is, as we understand it, as the fury of the feminist discourse of the $60 \mathrm{~s}, 70 \mathrm{~s},[\ldots]$ as a rejection of men, the condemnation of men.

These are the dominant meanings present in El Pais's representation of feminism: an extreme discourse that repudiates and convicts men. In addition, Padrón firmly believes that a feminist label would have hurt the telenovela's ratings. He argues that he needed to distance $E l$ Pais from this tag, which the media were beginning to impose on it, since the telenovela's title seemed to imply that women own the country. 
In sum, in El Pais no character wants to be a feminist since it is depicted as an aggressive, trite discourse present in the actions taken by women when they attempt to break with traditional gender roles. This is paradoxical, since the telenovela never gives feminism any credit for denouncing what El Pais attempts to criticize: a male dominated society in which gender roles are socially constructed. In this way, the production and representations of feminism in El Pais are deeply articulated and influenced by the commercial requirements of the telenovela genre. Feminism, then, is disconnected from the empowering message that Padrón attempts to deliver through El Pais, reflecting the separation of these two ideological constructs in the writer's mind.

This separation is also present in the audience's impressions of the telenovela. While most of the participants declare their understanding of El Pais's empowering message of women's redemption, its social critique, and its emphasis on the detrimental consequences of machismo, these men and women do not believe that the telenovela is feminist. In fact, most participants were either confused about the term, or had a negative opinion about it. "I find that nobody is sure about what it means" (BETTY, 30). "I don't know what it is. It sounds ugly, it's not something that I use" (AMANDA, 42). "It's not something used in my environment, I don't know what it means" (HILDA, 63). Some even confused the terms feminine and feminist:

If someone tells me, "you're so feminist," I feel that they're telling me that I dress too much like a woman. That is, instead of using pants, because I'm a woman I have to use skirts and high heels." (MARIA, 18)

In contrast, some participants felt that feminist and feminine are opposites. In this sense, they feel that feminism threatens the feminine, which they see as "the essence of being a woman" (ANTONIA, 19; CESAR, 41; CONSUELO, 18). For these participants, feminism is the masculinization of women. In short, they believe that "a woman has to be feminine, not feminist" (ANTONIA, 19).

A few of the audience members interviewed declared that feminism is a positive concept related to women's achievements and to their "struggle to be better" (ANA, 59) and "independent" (MILAGROS, 38). NELLY (19) believes that feminism provides ways for women "to defend themselves" from injustice. These positive associations, however, gave only partial understandings of feminism. Only two participants, MANUEL (30) and ANDREA (32) offered comprehensive definitions of feminism/feminist:

For me, feminism is the concretization of women's opportunity to use all their possibilities as complete human beings, without having to ask permission to others, simply asking themselves for permission. (MANUEL, 30)

I believe that a feminist is a person with a tendency to defend women's rights and women's position in society, since around the world women have been relegated. A feminist studies women's essence and understands that men and women have equal rights. (ANDREA, 32)

However, ANDREA clarified that this is not the country's general understanding of feminism:

In Venezuela, a feminist is a lesbian. A woman who doesn't like men ... and who attacks men. An obsessed woman. In Venezuela it's not a positive concept, not even among women. 
The rest of the participants agreed with this assessment. Many of them expressed views about feminism similar to the ones mentioned by $\mathrm{AN}$ DREA: man haters (CESAR, 41; JOSE, 18; NORA, 47), cuaimas (NELLY, 19), and, when the dichotomy feminine/feminist is carried to the extreme, lesbians (CESAR, 41).

There were some other negative meanings associated with feminism. For instance, PATRICIA (43) sees Ally $\mathrm{McBeal}$ as an example of a "classical feminist who is overqualified, sees men as inferior ... and is mistaken about many things. She thinks she is wonder woman.' This connotation of mistaken or extreme self-sufficiency was shared by other participants (ANTONIA, 19; CONSUELO, 18; GORINA, 18; JOSEFINA, 26; NINA, 20). In particular, NINA believes that feminists are not only overbearing, but also selfish:

It's a woman who doesn't allow herself to be pushed, and who does things because she wants, and not because she ought to. It's not good to be a feminist. It's not good that you think at all times only about yourself, and don't consider others.

Another selfish facet of feminism was described by MARIA (18), who suggested that feminists subordinate men by imposing behavior rules on them. "Feminists believe that men have to behave when they are with women, not because they want to, but because feminists expect them to."

All these meanings point to an understanding of feminism as an inverted form of machismo. "To me, feminism and machismo are the same in feminine and masculine," declared CLARA (43). MANUEL (30) explained that there is a predominant belief that "if machismo is the behavior of men who believe they are the bosses and women are there to serve them, feminism is the same but for women. They feel men exist to serve them." This conceptualization of feminism makes it undesirable for both men and women. This was illustrated by NORA (47), a psychologist who has worked extensively with battered women. Even though she was the participant with the highest level of awareness about machismo, domestic violence, deaths from illegal abortions, sexual harassment, and homophobia, she forcefully distanced herself from feminism:

NORA: You know that my friends and workmates say that I'm a feminist. But I tell them: "I'm not a feminist, I only defend women as human beings."

Interviewer: Why do you say that you are not a feminist?

NORA: Because they understand feminist as machista, OK? And that is not my position. I believe that men and women are equal human beings. The only thing that differentiates us is the biological. So, why the hell are they going to discriminate against me? And that doesn't mean I'm a feminist, that I don't like males, OK?

In sum, the production, representation, and consumption of feminism in El Pais are fraught with ambiguities and contradictions that are inextricably linked to the meanings associated with gender roles that circulate in the Venezuelan social formation.

\section{Conclusion}

The gradual but consistent way in which the word feminism has been substituted by the term estudios de género [gender studies] suggests the strength of Venezuela's rejection of the words feminism and feminist (personal correspondence with Gioconda Espina, 2001). Feminism is sensed as a threat 
to the established social order. This perception is at the root of resistance to the term. It is the end result of the fear that feminism implies a radical transformation of the Venezuelan social formation. In turn, this fear of change is the result of hegemony: the process of creating, preserving, and reproducing a dominant, authoritative set of meanings and practices - an ideology. Through negotiation and consent, a group of rules of conduct, signifying practices, and meanings are naturalized, becoming common sense, which Hall (1988, p. 45) defines as "a structure of popular ideology, a spontaneous conception of the world, reflecting the traces of previous systems of thought that have sedimented into everyday reasoning." Venezuelan common sense includes machismo and marianismo, and a strong men/public:women/private dichotomy that impinges on the definition of the feminine. Anything different is perceived as deviant and as a threat.

The dominance and pervasiveness of this Venezuelan common sense is illustrated in tensions between the commercial demands of the telenovela genre (high ratings) and the creative/ ideological requirements of the author. Padrón is ever mindful of the fine line he walks between delivering his message (women are strong, independent, and they belong in every aspect of Venezuelan life; machismo and abuse are wrong) and the cultural patterns that define his Venezuelan audience; hence, his efforts to distance Miranda from the gay label, and his seemingly paradoxical refusal to "do a feminist telenovela."

A closer look at the intricate workings of hegemony shows that it is "at its most adept when shifting ground to accommodate and deal with a threat to its order" (Brooker, 1998, p. 66). In other words, hegemony deploys efficient strategies that maintain the dominant (patriarchal) ideology as common sense. For instance, Padrón's and some of the participants' understanding of feminists as man haters is an example of labeling (Foucault, 1990) that disqualifies feminism and turns it into a threat. Another instance of labeling is the notion that feminists are selfish. This further disqualifies feminism since selfishness goes against the essence of marianismo, women's abnegation and selflessness. In addition, the widespread understanding of feminism as an inverse form of machismo also contributes to its neutralization. Men feel threatened by it, since feminism is about their subordination, and women reject it as an ideological construct that will make them behave like men do. Likewise, the conceptualization of feminism as the opposite of feminine places feminism on the deviant side of a binary opposition (Derrida, 1972), perpetuating the idea that feminists are not feminine, hence they are not acceptable or even normal. In the extreme form of this opposition, feminism is perceived as the masculinization of women. This, coupled with Venezuela's widespread homophobia, provides the ideological work necessary to move individuals towards labeling feminists as lesbians. Feminism, then, is squarely placed in the deviant category.

However, as Brooker (1998, p. 67) notes, hegemony can also "accept the threat into the mainstream, making it acceptable, domestic, trivial." El Pais de las Mujeres criticizes and mocks Venezuelan machismo and female subordination, providing women with characters/role models that illustrate how women can be legitimate protagonists of their own lives and interlocutors of reality. But, at the same time, 
El País ridicules feminism as a man hating, aggressive, emotional, out-ofplace discourse. These representations reflect the writer's own conceptualization of feminism and further encourage the public's rejection of the term. Participants believe that El Pais is a realistic and empowering rendition of the daily struggles of women in Venezuelan society. Most of those interviewed read (and appreciate) Padrón's message of justice for women. However, they do not understand these themes as feminist - a term they reject. In other words, in the production and consumption of this telenovela, feminism is divorced from messages that seek to empower women and improve their living conditions. In this way, feminist ideas - not acknowledged as feminist - are co-opted by the text. As the audience is seduced by El Pais's stories and characters, the same elements that successfully deliver the telenovela's message (casting, plot, and dialogue) also work successfully to discredit feminism. In the end, feminism is defused, robbed of its message, and labeled as deviant.

In Venezuela, telenovelas are an im- portant product that contributes to "the very material of ... daily life" (Willis, quoted in Turner, 1996, p. 2). This study suggests, yet again (Gurevitch \& Scannell, 2003; Hall, 1982; Johnson, 1986/87), that the communication process is never neutral. Writers, actors, media executives, texts and audiences are caught in a ritual process of establishing shared meanings, which is embedded in culture and power differentials.

The results of this study of the media production, representation, consumption and regulation of feminism both mirror and further the paradox faced by feminism worldwide. As a social movement, feminism has been central to the improvement of women's legal, social, political, economic, and cultural conditions around the world. Nevertheless, feminism has been widely stigmatized in all arenas, and its struggle for acceptance does not seem to abate. Therefore, even though Venezuelan women suffer subordinating conditions that are particular to their country, Venezuelan feminism faces challenges that are universal.

\section{Notes}

\footnotetext{
${ }^{1}$ Omar Calabrese calls this telenovelas neo-baroque (quoted in Steimberg, 1997). Oscar Steimberg defines them as stylistically postmodern. It is important to underscore the difference between telenovelas de ruptura and the entertainment-education telenovelas conceived by Miguel Sabido that were popular in the 1980s in Mexico and India (Nariman, 1993; Sherry, 1997; Singhal \& Rogers, 1999). Entertainment-education is defined as "a performance or spectacle that captures the interest or attention of individuals giving them pleasure and/or amusement [while simultaneously] delivering a program of instruction and training that has the potential to develop an individual's skill to achieve a particular end by boosting his or her mental, moral or physical powers" (Singhal \& Rogers, 1999, p. 10). In contrast, telenovelas de ruptura do not intend to educate, but attempt to chronicle and critique social reality.

${ }^{2}$ In addition, TV Azteca (Mexico) has bought the rights to El Pais de las Mujeres to do a remake adapted to Mexican culture.

${ }^{3}$ The men/public:women/private dichotomy has been widely analyzed by feminist scholars as an important ideological element of patriarchy (Okin, 1979; Pateman, 1988; Phillips, 1994). Even though
} 
the line between public and private has blurred, as Friedman (2000, p. 34) notes, "the gender relations based on it continue to inform contemporary political discourse."

${ }^{4}$ From 6.5 to 3.9 children per woman (Friedman, 2000).

${ }^{5}$ From $18 \%$ to $28 \%$ of the total workforce (Friedman, 2000).

${ }^{6}$ Of Venezuelan working women, $4 \%$ labor in the agricultural sector, $17 \%$ work in the industrial sector and $79 \%$ are employed in the service sector (Inter-American Development Bank, 1995).

${ }^{7}$ Unfortunately, this proved to be the correct strategy since opposition to the reform, attempting to halt it, claimed that the reform was "not a desire felt or shared by the majority of the Venezuelan people. At the most, it is shared by a small noisy group of divorced and feminist radicals" (paid ad quoted in Friedman, 2000, p. 183). In addition, in the Congress, Deputy Douglas Dagger asserted that "many of the articles of this proposal are conceived under completely feminist criteria according to which all vestige of authority in the heart of the family ought to be abolished" (quoted in Friedman, 2000, p. 183).

${ }^{8}$ Typing conventions will help to distinguish participants, characters, and production interviewees. Participants' names are capitalized and presented alongside their age, for example, NORA (47). The characters' names use the traditional combination of capitalizing the first letter, followed by lowercase letters, for example, Miranda. Emphasized words are italicized in the text.

${ }^{9}$ For instance, the character Almendra, whose name literally means almond, is referred to by the machista male characters as mi frutica [my fruit], and other delicious foods to be consumed. "Yo me la quería comer con mantequillita, como una cotufita [I wanted to eat her with butter, like popcorn]."

${ }^{10} \mathrm{In}$ Spanish the word serpent (and all its variations) is feminine: la serpiente, la culebra. Cuaima is a type of Venezuelan poisonous serpent. Referring to women as cuaimas is widespread among the country's male population. When El País was broadcast in Venezuela, many people referred to it as El País de las Cuaimas.

\section{References}

Allen, R.C. (1995). Introduction. In R.C. Allen (Ed.), To be continued ... soap operas around the world (pp. 1-26). London: Routledge.

Anderson, S. (1999). Reader's Digest on women: Antifeminist articulations. In M. Meyers (Ed.), Mediated women: Representations in popular culture (pp. 39-55). Cresskill, NJ: Hampton Press.

Aprea, G., \& Mendoza Martínez, R. (1996). Hacia una definición del género telenovela. In M. Soto (Ed.), Telenovela/ telenovelas. Los relatos de una historia de amor (pp. 17-30). Buenos Aires: Atuel - Colección del Círculo.

Baldwin, K. (1995). Montezuma's revenge: Reading Los Ricos Tambien Lloran in Russia. In R.C. Allen (Ed.), To be continued ... soap operas around the world (pp. 285-300). London: Routledge.

Barker, C. (2000). Cultural studies: Theory and practice. Thousand Oaks, CA: Sage.

Barrios, L. (1988). Television, telenovelas and family life in Venezuela. In J. Lull (Ed.), World families watch television (pp. 23-48). Newbury Park, CA: Sage.

Beltrán, L.R. (1978). TV etchings in the minds of Latin Americans: conservatism, materialism and conformism. Gazette, 24, 61-85.

Blum, L. (1983). Feminism and the mass media: A case study of The Women's Room as novel and television film. Berkeley Fournal of Sociology, 27, 1-26.

Borelli, S. H. (1997). Los géneros ficcionales en las telenovelas brasileñas. In E. Verón \& L.E. Chauvel (Eds.), Telenovela: Ficción popular y mutaciones culturales (pp. 169-178). Barcelona: Editorial Gedisa.

Bousquet, J.P. (1983). Las locas de Plaza de Mayo. Buenos Aires: El Cid.

Bouvard, M. (1994). Revolutionizing motherhood: The mothers of the Plaza de Mayo. Wilmington, DE: Scholarly Resources, Inc.

Brooker, W. (1998). Cultural studies. London: Hodder \& Stoughton.

Brown, M.E. (1994). Soap opera and women's talk. Thousand Oaks, CA: Sage.

Brundson, C. (2000). The feminist, the housewife, and the soap opera. Oxford: Oxford University Press. 
Bustos-Romero, O.L. (1993). Gender and mass media in Mexico: The receptors of soap operas. In A. Fadul (Ed.), Serial fiction in TV: the Latin American telenovelas (pp. 123-132). São Paulo: Universidad de São Paulo.

Cicerchia, R. (1997). The charm of family patterns: Historical and contemporary changes in Latin America. In E. Dore (Ed.), Gender politics in Latin America (pp. 118-133). New York: Monthly Review Press.

Clark, D. (1990). Cagney $\mathcal{E}$ Lacey: Feminist strategies of detection. In M.E. Brown (Ed.), Television and women's culture: The politics of the popular (pp. 116-133). Chapel Hill, NC: University of North Carolina Press.

Coccato, M. (1979). Apuntes para una historia de la telenovela venezolana. Video Forum, 2-3, 2-10.

Colomina de Rivera, M. (1974). El huesped alienante: un estudio sobre audiencia y efectos de las radio telenovelas en Venezuela. Maracaibo: Universidad del Zulia.

D'Acci, J. (1994). Defining women: Television and the case of Cagney $\mathcal{E}^{2}$ Lacey. Chapel Hill, NC: University of North Carolina Press.

Danner, L., \& Walsh, S. (1999). "Radical" feminists and "bickering" women: Backlash in U.S. media coverage of the United Nations Fourth World Conference on Women. Critical Studies in Mass Communication, 16, 63-84.

Dellinger-Pate, C., \& Aden, R.C. (1999). "More power!": Negotiating masculinity and femininity in Home Improvement. In M. Meyers (Ed.), Mediated women: Representations in popular culture (pp. 153-164). Cresskill, NJ: Hampton Press.

Derrida, J. (1972). Positions. Chicago, IL: University of Chicago Press.

Dore, E. (1997). Introduction: Controversies in gender politics. In E. Dore (Ed.), Gender politics in Latin America (pp. 9-18). New York: Monthly Review Press.

Dow, B.J. (1990). Hegemony, feminist criticism and The Mary Tyler Moore Show. Critical Studies in Mass Communication, 7, 261-274.

Dow, B.J. (1996). Prime time feminism: Television, media culture, and the women's movement since 1970. Philadelphia, PA: University of Pennsylvania Press.

du Gay, P., Hall, S. Janes, L., Mackay, H., \& Negus, K. (1997). Doing cultural studies: The story of the Sony Walkman. London: Sage.

Ellner, S. (1988). Venezuela's Movimiento al Socialismo: From guerrilla defeat to innovative politics. Durham, NC: Duke University Press.

Esteinou, R., \& Salles, V. (1996). Caminos sinuosos y rutas novedosas. Comisión de trabajo: género, sexualidad y familia. Estudios Latinoamericanos, 3, 243-259.

Estill, A. (2001). The Mexican telenovela and its foundational fictions. In E. Paz-Soldán \& D.A. Castillo (Eds.), Latin American literature and mass media (pp. 169-189). New York: Garland.

Fadul, A. (1993a). Serial fiction in TV: The Latin American telenovelas. São Paulo, Brazil: Universidad de São Paulo.

Fadul, A. (1993b). La telenovela brasileña y la búsqueda de las identidades nacionales. In $\mathrm{N}$. Mazziotti, E. Verón, J. Martín-Barbero, J.A. González, M.T. Quiroz, \& A. Fadul (Eds.), El espectáculo de la pasión (pp. 133-152). Buenos Aires: Colihue.

Faludi, S. (1991). Backlash: The undeclared war against American women. New York: Doubleday.

Foucault, M. (1990). The archaeology of knowledge. In P. Bizzell \& B. Herzberg (Eds.), The rhetorical tradition (pp. 1130-1154). Boston, MA: Bedford.

Friedman, E. (2000). Unfinished transitions: Women and the gendered development of democracy in Venezuela, 1936-1996. University Park, PA: Pennsylvania State University Press.

Garnham, N. (1997). Political economy and the practice of cultural studies. In M. Ferguson \& P. Golding (Eds.), Cultural studies in question (pp. 56-73). London: Sage.

Gazsó, G. (n.d.). Imágen de Venezuela. Caracas: Editorial Aurora.

Geddes-González, H. (1993). Articulating narrative strategies: The Peruvian telenovela. In A. Fadul 
(Ed.), Serial fiction in TV: the Latin American telenovelas (pp. 47-62). São Paulo: Universidad de São Paulo.

Goldman, R., Heath, D., \& Smith, S.L. (1991). Commodity feminism. Critical Studies in Mass Communication, 8, 333-351.

González, J.A. (1988). La cofradía de las emociones (in)terminables. I Parte: Construir las telenovelas mexicanas. Estudios sobre las Culturas Contemporáneas, 4-5, 13-65.

González, J.A. (1993). La cofradía de las emociones (in)terminables. In N. Mazziotti, E. Verón, J. Martín-Barbero, J.A. González, M.T. Quiroz, \& A. Fadul (Eds.), El espectáculo de la pasión (pp. 63-110). Buenos Aires: Colihue.

González de la Rocha, M. (1994). The resources of poverty: Women and survival in a Mexican city. Cambridge, MA: Basil Blackwell.

Goode, S. (1999, Nov. 29). Assessing the national vanity rate. Insight on the News, 15, 4.

Gramsci, A. (1971). The prison notebooks: Selections. New York: International Publishers.

Guaderrama, M. (1995). La construcción social de la telenovela en la prensa española. In G.Peñamarín \& P. López Díez (Eds.), Los melodramas televisivos y la cultura sentimental (pp. 139-155). Madrid: Universidad Complutense.

Gurevitch, M., \& Scannell, P. (2003). Canonization achieved? Stuart Hall's "encoding/decoding." In E. Katz, J. D. Peters, T. Liebes, \& A. Orloff (Eds.), Canonic texts in media research (pp. 231-247). Cambridge: Polity Press.

Hall, S. (1982). The rediscovery of "ideology": Return of the repressed in media studies. In M. Gurevitch, T. Bennet, J. Curran, \& J. Woollacott (Eds.), Culture, society and the media. (pp. 56-90). London: Methuen.

Hall, S. (1988). The toad in the garden: Thatcherism among the theorists. In C. Nelson \& L. Grossberg (Eds.), Marxism and the interpretation of culture (pp. 25-47).Urbana, IL: University of Illinois Press.

Hall, S. (1997). The work of representation. In S. Hall (Ed.), Representation: Cultural representations and signifying practices (pp. 13-74). London: Sage.

Hensman, R. (1996). The role of women in the resistance to political authoritarianism in Latin America and South Asia. In H. Afshar (Ed.), Women and politics in the third world (pp. 48-72). London: Routledge.

Hinds, H., \& Stacey, J. (2001). Imaging feminism, imaging femininity: The bra-burner, Diana and the woman who kills. Feminist Media Studies, 1, 153-177.

Hollows, J. (2000). Feminism, femininity and popular culture. Manchester: Manchester University Press.

Inter-American Bank (1995). Women in the Americas: Bridging the gender gap. Washington, DC: Inter-American Development Bank.

Jaquette, J.S. (1989). The women's movement in Latin America. Boston, MA: Unwin Hyman.

Jelin, E. (1990). Women and social change in Latin America. London: Zed Books.

Jensen, J., \& Pauly, J.J. (1997). Imagining the audience: losses and gains in cultural studies. In M. Ferguson \& P. Golding (Eds.), Cultural studies in question (pp. 155-169). London: Sage.

Johnson, R. (1986/87). What is cultural studies anyway? Social Text, 16, 38-80.

Juliano, D. (1998). Las que saben: Subculturas de mujeres. Madrid: Horas y Horas.

Kitzinger, J. (2001). Transformations of public and private knowledge: Audience reception, feminism and the experience of childhood sexual abuse. Feminist Media Studies, 1, 91-104.

Klagsbrunn, M. (1993). The Brazilian telenovela: A genre in development. In A.M. Fadul (Ed.), Serial fiction in TV: The Latin American telenovelas (pp. 15-24). São Paulo: Universidad de São Paulo.

Klagsbrunn, M. (1997). La telenovela brasileña: un género en desarrollo. In E. Verón \& L.E. Chauvel (Eds.), Telenovela: Ficción popular y mutaciones culturales (pp. 1153-168). Barcelona: Editorial Gedisa.

Lager, E. (1992). Las razones de una pasión: Análisis de Topacio. In J. Martín-Barbero \& S. Muñoz (Eds.), Televisión y melodrama: Género y lecturas de la telenovela en Colombia (pp. 139-175). Bogotá: Tercer Mundo. 
La Pastina, A. (2001). Product placement in Brazilian prime-time television: The case of a telenovela reception. Fournal of Broadcasting and Electronic Media, 45, 541-557.

Levine, E. (2001). Toward a research paradigm for media production research: Behind the scenes at General Hospital. Critical Studies in Media Communication, 18, 66-82.

Lind, R.A., \& Salo, C. (2002). The framing of feminists and feminism in news and public affairs programs in U.S. electronic media. Fournal of Communication, 52, 211-228.

Lopez, A.M. (1995). Our welcomed guests, telenovelas in Latin America. In R.C. Allen (Ed.), To be continued ... soap operas around the world (pp. 256-275). London: Routledge.

Lotz, A.D. (2001). Postfeminist television criticism: Rehabilitating critical terms and identifying postfeminist attributes. Feminist Media Studies, 1, 105-121.

Lozano, E. (1989). Soap operas and telenovelas: An intercultural critique of soap operas as feminine discourse. Paper presented at the Annual Meeting of the International Communication Association. San Francisco, CA.

Lumby, C. (1997). Bad girls: The media, sex and feminism in the '90s. St. Leonards: Allen \& Unwin.

Martín-Barbero, J. (1987). De los medios a las mediaciones: Comunicación, cultura y hegemonía. Barcelona: Editorial Gustavo Gili.

Martín-Barbero, J. (1988). Matrices culturales de las telenovelas. Estudios sobre las culturas contemporáneas, 2, $137-163$.

Martín-Barbero, J. (1993). La telenovela en Colombia. Televisión, melodrama y vida cotidiana. In N. Mazziotti, E. Verón, J. Martín-Barbero, J.A. González, M.T. Quiroz, \& A. Fadul (Eds.), El espectáculo de la pasión (pp. 43-62). Buenos Aires: Colihue.

Martín-Barbero, J. (1995). Memory and form in the Latin American soap opera. In R. C. Allen (Ed.), To be continued ... soap operas around the world (pp. 276-284). London: Routledge.

Martín-Barbero, J., \& Muñoz, S. (Eds.). (1992). Televisión y melodrama: Género y lecturas de la telenovela en Colombia. Bogotá: Tercer Mundo.

Martín-Barbero, J., \& Rey, G. (1999). Los ejercicios del ver: hegemonía audiovisual y ficción televisiva. Barcelona: Editorial Gedisa.

Matelski, M. (1999). Soap operas worldwide: Cultural and serial realities. Jefferson, NC: McFarland.

Mayne, J. (1997). L.A. Law and prime-time feminism. In C. Brudnson, J. D’Acci, \& L. Spigel (Eds.), Feminist television criticism: A reader (pp. 84-97). New York: Oxford University Press.

Mazziotti, N., \& Borda, L. (1997). Telenovelas argentinas: Andrea del Boca en los 90. In E. Verón \& L.E. Chauvel (Eds.), Telenovela: Ficción popular y mutaciones culturales (pp. 143-152). Barcelona: Editorial Gedisa.

McAnany, E.G., \& La Pastina, A.C. (1994). Telenovela audiences: A review and methodological critique of Latin America research. Communication Research, 21, 828-849.

McClenaghan, S. (1997). Women, work and empowerment: Romanticizing the reality. In E. Dore (Ed.), Gender politics in Latin America (pp. 19-35). New York: Monthly Review Press.

Mellencamp, P. (1997). Situation comedy, feminism, and Freud: Discourses of Gracie and Lucy. In C. Brundson, J. D'Acci, \& L. Spigel (Eds.), Feminist television criticism: A reader_pp. 60-73). New York: Oxford University Press.

Mendoza, M.I. (n.d.). La telenovela venzolana: de artesanal a industrial. Retrieved March 1, 2003 from http:// www.felafacs.org/dialogos/pdf44/2Inés.pdf

Moraña, O. (1978). Para una aproximación semiológica a la telenovela. Video Forum, 1-5, 12-28.

Muñoz, S. (1992). Mundos de vida y modos de ver. In J. Martín-Barbero \& S. Muñoz (Eds.), Televisión y melodrama: Género y lecturas de la telenovela en Colombia (pp. 233-294). Bogotá: Tercer Mundo.

Murphy, P.D. (1997). Contrasting perspectives; cultural studies in Latin America and the United States: A conversation with Néstor García Canclini. Cultural Studies, 11, 78-88.

Nariman, H.N. (1993). Soap operas for social change: Toward a methodology for entertainment-education television. Westport, CT: Praeger.

Navarro, M. (1989). The personal is political: Las Madres de Plaza de Mayo. In S. Eckstein (Ed.), Power and popular protest: Latin American social movements (pp. 241-258). Berkley, CA: University of California Press. 
O'Connor, A. (1991). The emergence of cultural studies in Latin America. Critical Studies in Mass Communication, 8, 60-73.

O'Donnell, H. (1999). Good times and bad times: Soap operas and society in Western Europe. London: Leicester University Press.

Okin, S. (1979). Women in Western political thought. Princeton, NJ: Princeton University Press.

Pateman, C. (1988). The sexual contract. Stanford, CA: Stanford University Press.

Phillips, A. (1994). Must feminists give up on liberal democracy? Political studies, 40, 93-111.

Porto, M.P. (1998). Telenovelas and politics in the 1994 Brazilian presidential election. The Communication Review, 2, 433-459.

Pozzato, M.P. (1995). El "rosa" como función antropológica y como género multimedia. In C. Peñamarín \& P. López Díez (Eds.), Los melodramas televisivos y la cultura sentimental (pp. 41-50). Madrid: Universidad Complutense.

Press, A.L. (1991). Women watching television: Gender, class and generation in the American television experience. Philadelphia, PA: University of Pennsylvania Press.

Probyn, E. (2001). Teaching in the field: Gender and feminist media studies. Feminist Media Studies, 1 , 35-39.

Proyecto Pobreza (2002). Retrieved October 10, 2002 from https://omega.manapro.com/pobreza/ index $1 . h \mathrm{hm}$

Quiroz, M.T. (1993). La telenovela en el Peru. In A. Fadul (Ed.), Serial fiction in TV: The Latin American telenovelas (pp. 33-46). São Paulo: Universidad de São Paulo.

Rabinovitz, L. (1989). Sitcoms and single moms: Representations of feminism on American TV. Cinema fournal, 29, 3-19.

Rabinovitz, L. (1999). Ms.-Representation: The politics of feminist sitcoms. In M.B. Haralovich \& L. Rabinovitz (Eds.), Television, history, and American culture (pp. 144-167). Durham, NG: Duke University Press.

Read, J. (2000). The new avengers: Feminism, femininity and the rape-revenge cycle. Manchester: Manchester University Press.

Rector, M. (1975). A televisão e a telenovela. Revista Cultura, 18, 112-117.

Rogers, E. M., \& Antola, L. (1985). Telenovelas: A Latin American success story. Fournal of Communication, 35, 24-35.

Rohter, L. (2000, August 13). Who is vainest of all? New York Times, p. 1-10.

Rubin, L.B. (1986). Worlds of pain: Life in the working-class family. New York: Basic Books.

Schirmer, J.G. (1993). Those who die for life cannot be called dead: Women and human rights protest in Latin America. In M. Agosin (Ed.), Surviving beyond fear: Women, children and human rights in Latin America (pp. 31-57). Fredonia, NY: White Pine Press.

Sherry, J. (1997). Prosocial soap operas for development: A review of research and theory. The Fournal of International Communication, 4, 75-101.

Singhal, A., \& Rogers, E.M. (1999). Entertainment-education: A communication strategy for social change. Mahwah, NJ: Lawrence Erlbaum.

Sluyter-Beltrão, M. (1993). Interpreting Brazilian telenovelas: Biography and fiction in a rural-urban audience. In A. Fadul (Ed.), Serial fiction in TV: the Latin American telenovelas (pp. 63-76). São Paulo: Universidad de São Paulo.

Sodré, M. (1977). O monopolio da fala. Petrópolis: Vozes.

Steimberg, O. (1997). Estilo contemporáneo y desarticulación narrativa. Nuevos presentes, nuevos pasados de la telenovela. In E. Verón \& L.E. Chauvel (Eds.), Telenovela: Ficción popular y mutaciones culturales (pp. 17-28). Barcelona: Editorial Gedisa.

Stephen, L. (1997). Women and social movements in Latin America: Power from below. Austin, TX: University of Texas Press.

Stevens, E. (1973). Marianismo: The other face of machismo in Latin America. In A. Pescatello (Ed.), Female and male in Latin America (pp. 89-102). Pittsburgh, PA: University of Pittsburgh Press. 
Straubhaar, J. (1988). The reflection of the Brazilian political liberalization in the telenovela, 1974-1984. Studies in Latin American Popular Culture, 7, 59-76.

Tavola, A. (1984). A liberdade do ver. Rio de Janeiro: Nova Fronteira.

Tufte, T. (1993). Everyday life, women and telenovelas in Brazil. In A. Fadul (Ed.), Serial fiction in TV: the Latin American telenovelas (pp. 77-101). São Paulo: Universidad de São Paulo.

Tufte, T. (2000). Liwing with the rubbish queen: Telenovelas, culture and modernity in Brazil. Luton, UK: University of Luton Press.

Turner, G. (1996). British cultural studies. London: Routledge.

Uribe Alvarado, A.B. (1993). La telenovela en la vida familiar cotidiana en México. In A. Fadul (Ed.), Serial fiction in TV: the Latin American telenovelas (pp. 103-122). São Paulo: Universidad de São Paulo.

van Zoonen, L. (1994). Feminist media studies. London: Sage.

Verón, E. (1978). Relato televisivo e imaginario social. In N. Mazziotti (Ed.), El espectáculo de la passion (pp. 10-42). Buenos Aires: Colihue.

Verón, E., \& Chauvel, L.E. (Eds.). (1997). Telenovela: Ficción popular y mutaciones culturales. Barcelona: Gedisa.

Vink, N. (1988). The telenovela and emancipation. Amsterdam: Royal Tropical Institute.

Weiss, R. (1994). Learning from strangers: The art and method of qualitative interview studies. New York: The Free Press.

Whelehan, I. (2000). Overloaded: Popular culture and the future of feminism. London: The Women's Press.

Received August 23, 2001

Final revision received January 30, 2003

Accepted February 7, 2003 